\title{
Networks and the Diffusion of Off-Grid Solar Technologies
}

\author{
Kartikeya Singh \\ Center for Strategic \& International Studies, Washington D.C., USA \\ Email: Ksingh@csis.org
}

How to cite this paper: Singh, K. (2017) Networks and the Diffusion of Off-Grid Solar Technologies. Low Carbon Economy, 8, 63-80.

https://doi.org/10.4236/lce.2017.82006

Received: September 16, 2016

Accepted: June 19, 2017

Published: June 22, 2017

Copyright $\odot 2017$ by author and Scientific Research Publishing Inc. This work is licensed under the Creative Commons Attribution International License (CC BY 4.0).

http://creativecommons.org/licenses/by/4.0/

(c) (i) Open Access

\begin{abstract}
Nearly 1.2 billion people on the planet still lack access to electricity, 250 million of whom reside in India. Off-grid solar technologies can help meet some of the energy needs of these people but have faced a variety of financial, technical, and political barriers. Pro-poor innovation, led by emerging enterprises such as Green Light Planet (GLP), holds the key to understanding how low carbon technologies such as off-grid solar might achieve scale. This case study builds on prior research examining what factors affect the ability of an offgrid solar firm to achieve scale in India by examining the most successful company in terms of unit sales. Through that extensive research of the off-grid market in India, it was revealed that GLP far outsold other companies in its class around 2015. One of the factors affecting its ability to scale is the fact that its products are modular and require little to no financing for the customers. This case study further reveals that the company's main innovation is the business model, which relies on networks of sales agents operating under a system of sales targets, incentives and boosters. By shifting the responsibility of making sales to last-mile entrepreneurs, the company leverages its network to continuously move inventory off the shelf and into the hands of customers.
\end{abstract}

\section{Keywords}

Energy Access, Decentralized Energy, Diffusion, Entrepreneurship, Solar, India

\section{Introduction}

Achieving universal access to modern energy has become enshrined in the new U.N. Sustainable Development Goals [1] because of its related effects on human development [2]. Doing so with low-carbon technologies is paramount given the need for deep decarbonization in a climate-constrained global carbon budget [3] 
[4] [5]. Off-grid solar technologies provide a potential mechanism for meeting the twin goals of establishing universal energy access and low-carbon technology diffusion. This paper contributes to scholarship about what factors affect the scaling up, or not, of off-grid solar technologies in India, that largest single market of people without modern electricity access [6]. Authors cite various barriers to the diffusion of these technologies, beyond the technical characteristics [7], particularly for the last mile customer [8] [9] [10] [11]. Through the lens of innovation and diffusion theories, this specific case study unpacks in detail how a firm can achieve success in unit scaling and overcome some of the barriers identified by scholars and practitioners.

Schumpeter [12] highlighted the role of the entrepreneur in driving innovation: being the agent who disrupts the existing system and generates new wealth through new combinations of existing materials and processes. Agbemabiese [13] argues that beyond the individual, "it is generally the case that multiple interacting actors, institutions and functions are involved in the process" of transforming an invention (a material or process created by an entrepreneur) into an innovation that is diffused to a broader audience. Barnett [14] would add that "the analysis of the diffusion of energy technologies [the focus of this study] should at least try to identify the key actors in the process and to understand the environment in which they operate: an environment formed by their objectives, their resources, the technology available to them and the market they face." Research about the success and failures of innovations suggests that fundamentally, an innovation must meet the user's needs [15] and thus the understanding of specific needs of technology users is critical [16]. Finally, the processes that facilitate the creation of knowledge or "learning" for a firm are powerful drivers of innovation and form a critical part of the energy technology innovation system [17].

Suurs [18] categorizes the actors in a technology innovation system as either enactors (those responsible for the creation of a specific technology or process) or selectors (those who choose from a variety of technological options to address a particular problem). The role of the energy access firm as either an enactor or a selector would therefore have an impact on its ability to diffuse off-grid solar technologies. Rogers [19] emphasized that perceptions of technology, as well as locally present indigenous knowledge systems can play a large role in the diffusion and acceptance of technologies. In addition to a technology's attributes, that can influence its "rate of adoption", there are other culturally dependent factors, including the nature of communication channels diffusing the innovation, the role and respect of early adopters in communities, as well as the amount of social capital and associational activity within those communities [20]. Specifically, Rogers states that diffusion happens through certain channels (interpersonal or mass media), over time (influenced by the rates of adoption, the innovation-decision process, and the innovativeness of the individual) and facilitated by certain people (pre-existing opinion leaders in a community or change agents arriving from outside the community).

The role of networks, specifically social [21] or communication networks [22] 
[23], in some of the emergent business models for distributing off-grid solar technologies is critical to the diffusion of such innovations [24]. Rogers defines a communication network as "interconnected individuals who are linked by patterned flows of information" [19]. Specifically, it is the opinion leader's "interpersonal networks that allow him or her to serve as a social model whose innovative behavior is imitated by many other members of the systems". Energy innovations that utilize such networks would be categorized by Tawney [25] as part of the process that explicitly targets the poor as end-users of the resulting solutions, or "pro-poor energy innovations".

The problem of inadequate investment in pro-poor energy, a major barrier to scaling energy access, has been compounded by the fact that the energy sector suffers more broadly from chronically low investment in innovation [26]. Supporting firms and ecosystems that birth scalable pro-poor energy innovations is critical to achieving universal energy access for all. This case study provides a closer look at an innovative pro-poor off-grid solar energy enterprise in India that has scaled in units of products sold, which yields insights into elements of successful business models and the ecosystems required to support such firms.

\section{Methods}

This paper presents an in-depth case study of how unit scaling can be achieved for pro-poor energy innovation. It is part of a broader research endeavor aimed at understanding which firm-level factors affect the scaling-up (or not) of offgrid solar technologies in India [6]. Methodologies drawn from for this study include both quantitative and qualitative analysis. This analysis revealed that the most successful firm identified by unit scale was Green Light Planet. While one case study cannot conclusively prove anything, there is intrinsic value in a detailed analysis of what appears to be one of the most successful cases. To explore in detail factors that may be affecting the firm's ability to achieve scale, in-depth qualitative analysis was required. Using the methodologies employed in this paper, further research should explore other firms using business models similar to or different from the direct marketing approach of GLP. A compilation of such cases would enhance the understanding of the role of networks in the diffusion of off-grid solar technologies in India.

The main tool used for qualitative inquiry were semi-structured interviews conducted with various employees of the company, including the CEO, the head of the Service Center in Patna, the acting District Manager responsible for Vaishali District, a Team Leader and two Sales Business Associates. The purpose of these interviews was to understand in greater detail the evolution of GLP's business plan and the challenges faced and opportunities leveraged as the firm grew in size and customer base. In addition, a randomized structured survey was conducted of 15 Green Light Planet customers in several villages of Vaishali district in the eastern state of Bihar in July 2014 (see Figure 1). Vaishali was selected because it would allow for the evaluation of GLP's full ecosystem of technology deployment (including the only service center in the state). The 


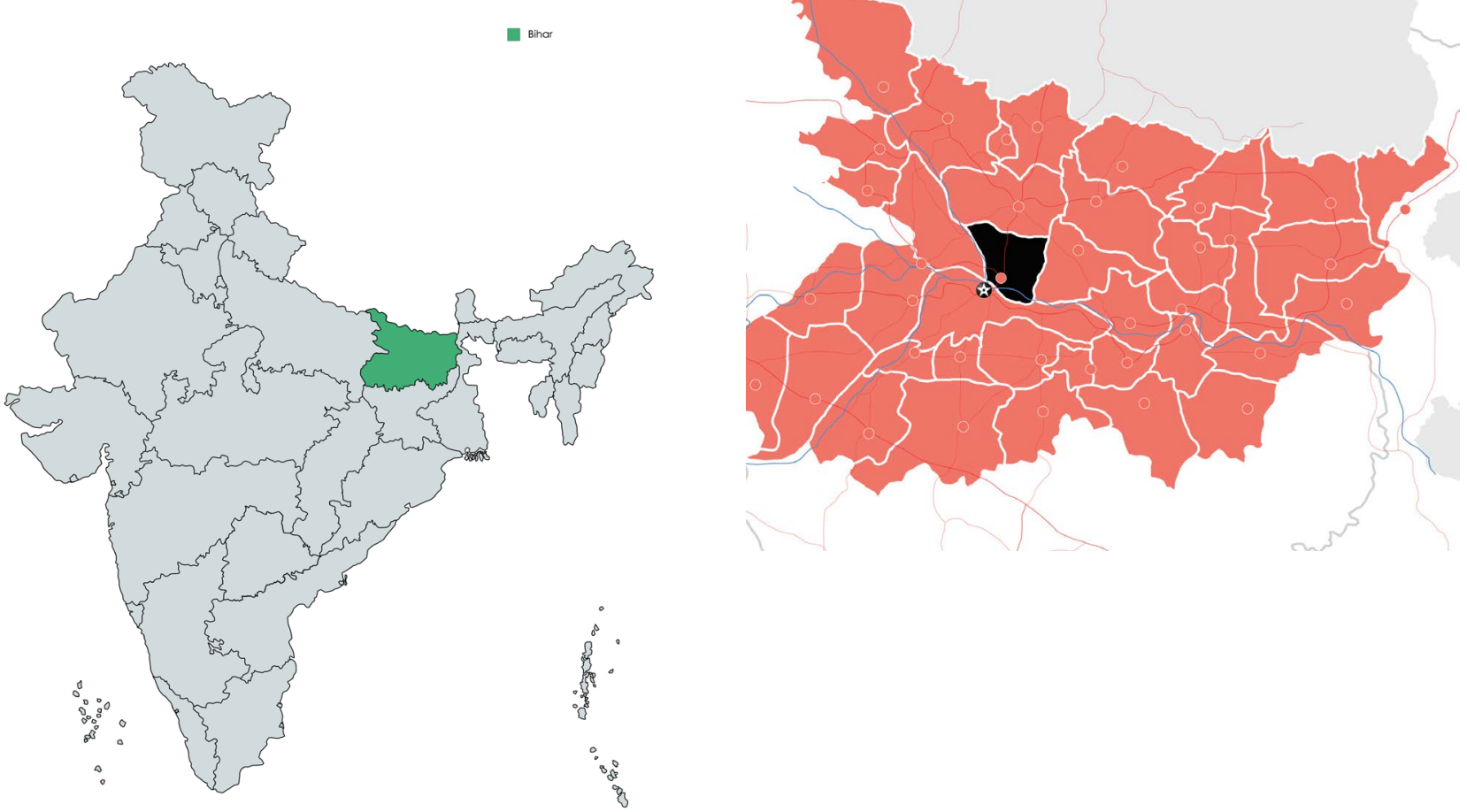

Figure 1. The map on the left depicts the location of the state of Bihar in India while the map on the right depicts Vaishali District in the state of Bihar.

interviews were designed to assess: 1) the demographics of the customer base of off-grid solar technology firms; 2) finance and the technology; 3) servicing and maintenance issues; 4) fuel switching; 5) quality and satisfaction; and 6) livelihood improvement or augmentation. The purpose of these surveys were to verify responses of GLP staff as well as identify the challenges and opportunities post-deployment of the company's business model.

The author also participated in a few sales attempts with a local sales agent of Green Light Planet to better understand the sales strategy and witness the interaction between potential customers and the company. To identify and analyze the role of social networks in GLP's business model, a combination of observation, process tracing, content analysis, and constant comparison were utilized. When examining the impact of each customer helping diffuse the technology further as in Figure 2, due to limited data and simply to provide a snapshot, an improvised visual graphic was created in lieu of the graph theory methods used in traditional actor centrality and prestige-based social network analysis [27].

\section{Results}

Green Light Planet is a private enterprise that manufactures and sells off-grid solar energy technologies across India. The company's products, predominantly a variety of solar lanterns ${ }^{1}$, with or without mobile phone charging capability

${ }^{1}$ Shortly after the survey was conducted, GLP expanded its line of products and entered a new market segment by introducing a solar home lighting system. 


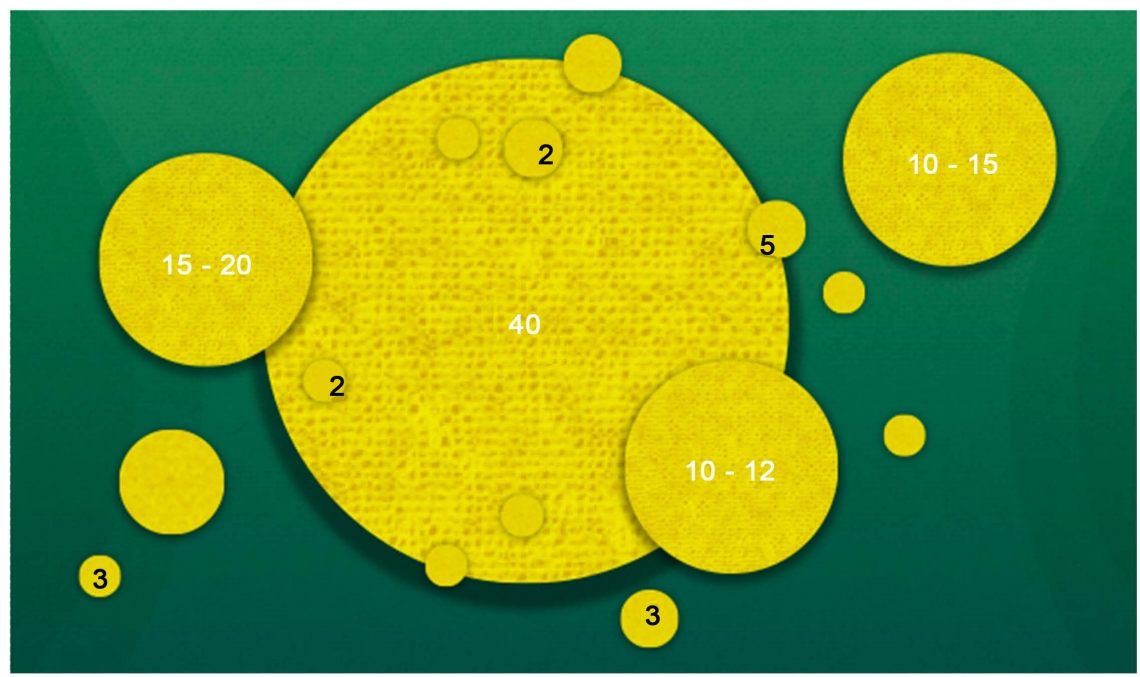

Figure 2. Sales driven through word of mouth by GLP customers themselves.

(see Table 1) are branded as Sun King products so that they can be sold through partners as well as directly by GLP. GLP's pathway to growth started with a combination of early stage technology development, trials and learning for the corporation coupled with capital infusions (see Figure 3). The scaling of GLP's business is best understood by examining the evolution and architecture of its innovation related to deployment.

\section{1) Deployment Model Innovation}

GLP is one of the few companies in India utilizing village level entrepreneur networks (VLE) that facilitate the sales of their products to the "last mile". Bairiganjan and Sanyal [28] describe a VLE as a "local village based individual who acts as the last mile to reach consumers, thus improving access for the low-income population to diverse products by taking on market innovations at the grass roots level". Also called the "direct marketing concept" or "direct sales model", it relies heavily on these grassroots sales agents who leverage the communication networks described by Rogers for the diffusion of innovations [19]. There are no shops from which sales are made; rather, the agents sell directly to members in their community. The direct sales model faced initial challenges such as appropriate partner selection, difficulty in establishing a supply chain and cultural as well as financial barriers that affected staffing in certain geographies, but emerged successfully over time. In June 2009 GLP started out partnering with the education-focused NGO Pratham in Orissa. Their tutors served as sales agents of the Sun King Eco lantern. By October, however, $90 \%$ of the staff were fired because funding from Pratham stopped. GLP also learned that in states like Karnatakathe model did not work, causing operations in that state to cease. The failure in Karnataka may have been due to cultural factors such as the unwillingness of people to perform door-to-door sales. Bihar, the state in which this model has thrived, took three years to mature.

\section{Organizational Chart}

In the direct sales model, GLP organizes its staff into the following categories: 


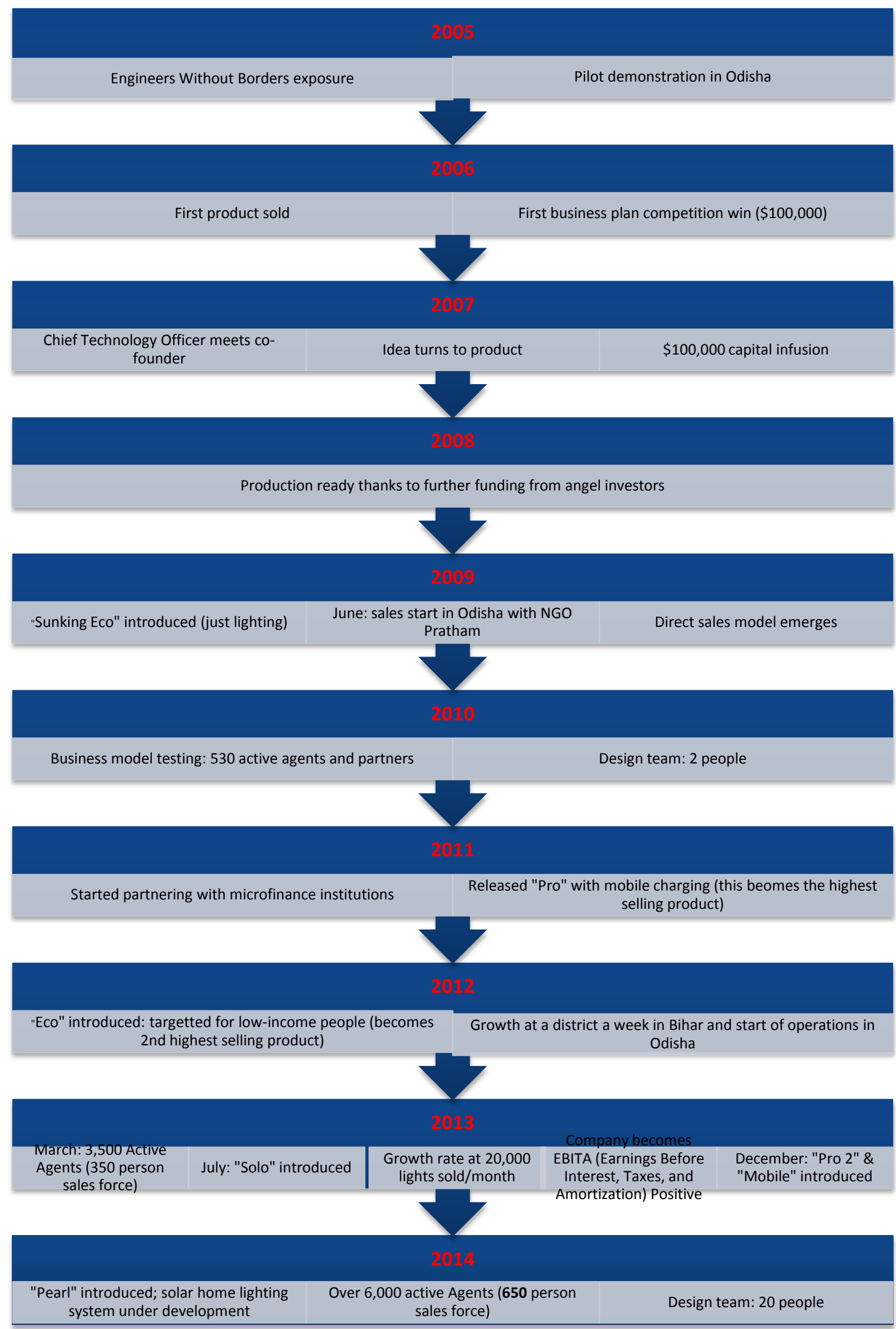

Figure 3. Timeline of growth of green light planet. 
Table 1. List of Sun King products' prices and specifications.

\begin{tabular}{|c|c|c|c|c|c|}
\hline $\begin{array}{l}\text { Product } \\
\text { Type }\end{array}$ & $\begin{array}{l}\text { Retail } \\
\text { Price }\end{array}$ & $\begin{array}{l}\text { Solar } \\
\text { Power }\end{array}$ & $\begin{array}{c}\text { Daily } \\
\text { Run-Time }^{1}\end{array}$ & Brightness $^{2}$ & $\begin{array}{l}\text { Mobile Phone } \\
\text { Charger }\end{array}$ \\
\hline Eco & $\$ 17.99$ & $500 \mathrm{~mW}>$ & 30 hours & $\begin{array}{c}25 \text { lumens } \\
(2 \times \text { kerosene })\end{array}$ & No \\
\hline Solo & $\$ 24.99$ & $700 \mathrm{~mW}>$ & 24 hours & $\begin{array}{c}50 \text { lumens } \\
(5 \times \text { kerosene })\end{array}$ & No \\
\hline Mobile & $\$ 29.99$ & $1.5 \mathrm{~W}>$ & 36 hours & $\begin{array}{c}75 \text { lumens } \\
(8 \times \text { kerosene })\end{array}$ & $1 \times$ USB charger \\
\hline Pro2 & $\$ 49.99$ & $3.3 \mathrm{~W}>$ & 36 hours & $\begin{array}{c}150 \text { lumens } \\
(15 \times \text { kerosene })\end{array}$ & $2 \times$ USB charger \\
\hline
\end{tabular}

1. Sun King uses Lithium-ferro phosphate batteries that last 5 years. 2. Max lumens depending on setting chosen and the approximate brightness as compared to kerosene lamp.

- A Zonal Business Manager (ZBM) is incharge of a particular state.

- Several Regional Sales Managers (RSM) look after a few districts each and report to the ZBM.

- Each District Sales Manager (DSM) is responsible for the management of sales in his district and report directly to the RSM.

- Up to eight Team Leaders (TL) are responsible for the management of sales in several villages and report directly to the DSM incharge of the area.

- Each TL manages up to 16 Sales Business Associates (SBA) who are responsible for sales in their own villages.

The role of this extensive, organized network in facilitating sales is evidenced by the increase in revenue through sales in the state of Bihar from approximately $\$ 70,000$ per month in 2012 to approximately $\$ 417,000$ per month in 2014(see Figure 4). This growth is attributed to the fact that the number of District Sales Managers (DSMs), Team Leaders (TLs) and Sales Business Associates (SBAs) have dramatically increased in that two year period ${ }^{2}$.

Every staff category is salaried on the GLP payroll, except the SBAs who work on $10 \%$ commission per product sold. There is constant communication and coordination for sales, demonstrations, and meeting of targets between the DSMs, TLs, and SBAs. There is a monthly review meeting between the DSM, RSM and ZM. All TLs meet with the DSM in the district once a week, and a RSM may meet with the DSM 3 - 4 times a month. Furthermore, GLP even facilitates the cross-pollination of ideas between its staff in India and East Africa through exchanges. The constant sharing of information through this network probably allows for greater diffusion of GLP's technology. Finally it should be noted that GLP could be classified as both an enactor as well as a selector in Suurs' [18] categorization of actors in the technology innovation system. It can be classified as

${ }^{2}$ This case study is confined to GLP's organizational structure in the state of Bihar, as described above. However, it is already evolving in other parts of the country. The future of sales for GLP hinges on the introduction of a "super agent", which replaces the role of the TL. The super agent is not salaried by GLP, which removes another fixed cost for the company thereby increasing profitability. At the time of the field visit the super agent model had already expanded to 100 districts in the states of Uttar Pradesh, Rajasthan, Jharkand and the North Eastern Region states. 


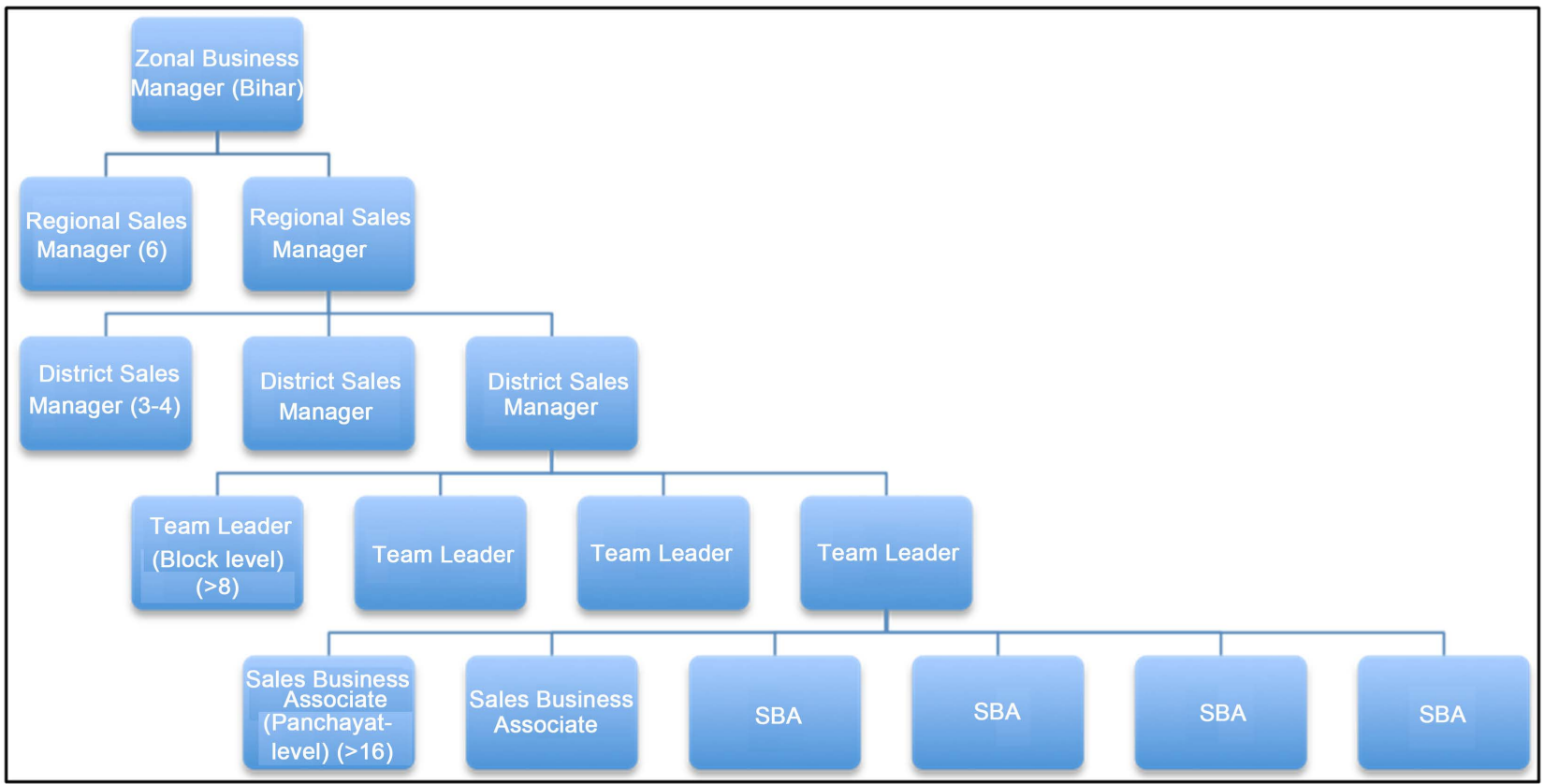

Figure 4. Direct marketing organizational chart (example from Bihar).

both because GLP not only creates its own technology but its network of sales agents pick and choose which combination of technologies sell best in their area.

\section{Supply Chain}

A supply chain is defined by Mentzer et al. [29] as "a set of three or more entitites (organizations or individuals) directly involved in the upstream and downstream flows of products, services, finances, and/or information from a source to a customer". Establishing a well functioning supply chain for the distribution of technologies and for their maintenance is critical for the success of any off-grid solar energy enterprise. GLP keeps one stock point for all its products per district. The district needs to generate monthly sales of $\$ 6,667$ in order for GLP to establish a stock point and transporter in the locality. The stock point is kept with 12 days of stock for each product. To find a good distributor/stock keeper, GLP undertakes a market survey in the region to determine who is stocking products for reputed companies. Stock keepers have a $3.75 \%$ margin on sales which is capped at $\$ 250 /$ month. The stock keeper hires a transporter and allocates approximately $\$ 70$ for this including fuel charges.

A Team Leader is responsible for buying inventory from GLP through the stock point and selling it to the SBA. SBAs are far from stock points so they rely on the Team Leaders to purchase products for them. This arrangement reduces the transportation costs for the SBA as well. The SBA generally purchases two pieces of each product from the TL.

\section{Sales Business Associate (SBA)}

The primary role of the SBA is to motivate the customer to purchase GLP products. Nearly all of them do their job part time, choosing to focus on sales either in the morning or evening hours. One of the SBAs interviewed during the study, has been with GLP for almost two years. He also serves as a lab technician 
for a pharmaceutical company while his family operates an after-school tutoring center and engages in agriculture. Another SBA interviewed, is an influential man in his village who has been with GLP for nearly a year and is known to be one of the company's most successful SBAs. In addition to his duties as an SBA, he operates a poultry farm.

Recalling the importance of knowing the user's needs when trying to diffuse an innovation [16], field interviews confirmed that SBAs must have a detailed understanding of why a customer is not purchasing products, and where there is unmet demand for electricity from the grid. For example, a potential customer may consider GLP's products too expensive when compared to alternative products available in the market. Or, the number of small business owners in a village may be higher than in another, driving up the demand for off-grid solar products in that location. Some villages may also have a more erratic electricity supply than others making the residents there more interested in supplementing their supply through solar energy. In addition, SBAs must know the paying capacity of their clients, which is useful for GLP to establish price points for their various products. One of the SBA's stated that his customers are "too poor" to be able to afford the products. Coupled with the fact that he is selling to his relatives and friends, he has gotten in the habit of taking payments from the customers in installments instead of full payments. Acting as a micro-lender has resulted in debt accumulation, which he was tracking in a little book he presented at the time of the field visit. A bit frustrated with the situation, he stated, "this is the business of tying the noose of debt around people's necks". Finally, SBAs may have overlapping territories, or two or more SBAs may reside in the same territory but sell to people in neighboring villages or hamlets. Being in close proximity highlights the continued role of communication networks in the diffusion of innovations as it facilitates knowledge sharing between SBAs in how and where to make sales in addition to driving competition to meet individual monthly sales targets.

Direct sales is a difficult job. It takes approximately 30 - 40 minutes for a SBA to convince the customer and requires on average 3 - 4 visits as well. The sales pitch typically starts with the health challenges of using kerosene and a cost-benefit analysis of switching from kerosene to a solar lantern. For example, on average a person in Bihar might spend Rs. $10(\$ 0.17)$ a day on kerosene. Similarly, a person might spend Rs. 150 (\$2.50) a month for approximately 3 hours a day of use to get access to a diesel generator-based plug point connection (for mobile charging).

The GLP model is also unique because it shifts the risk of completing sales from the parent corporation to its network of sales agents. All SBAs have targets for monthly sales that are set for them by District Sales Managers and facilitated with the help of Team Leaders. Both SBAs and TLs are under immense pressure to meet monthly sales targets. To meet these targets, TLs take on high inventory loans from GLP and pass these loans on to SBAs (see Table 2). This way, GLP gets the product off its shelf and into the homes of customers much faster than a traditional solar company whose stock may sit in warehouses and stockpoints 
Table 2. Monthly debt acquired by GLP staff.

\begin{tabular}{cc}
\hline Debtor & Monthly Debt (USD) \\
\hline Team Leader & $\$ 833-\$ 1667$ \\
Sales Business Associate & $\$ 167-\$ 334$ \\
\hline
\end{tabular}

for a much longer time with a dealer. The desire to get rid of inventory debt drives sales. Though this model results in relatively high sales, the pressure to meet targets (and to carry debt) results in a low retention rate of $50 \%-60 \%$ for SBAs in the GLP network.

Sales vary from region to region with some SBAs managing to sell up to 80 pieces a month. The average monthly products and highest ever sales per month for the two SBAs interviewed for this study are listed in Table 3. In the district that was surveyed, there is electricity access so sales for an SBA have never reached as high as 80 products a month.

\section{Team Leader}

A good Team Leader has prior experience in marketing and distribution. One of the Team Leaders interviewed during the field visit to Vaishali district in Bihar previously worked with Aircell, a cellular network provider, for two years in a marketing position. Working fulltime dealing with his SBAs, he must reach out to at least two of them a day to ensure that they are meeting their sales targets. Through all his combined SBAs, a Team Leader should average $\$ 167$ in sales a day. In June of 2014, prior to the field visit, the TL interviewed executed $\$ 6,667$ in sales with the help of his 21 SBAs.

\section{Commission and Incentive Structures}

As mentioned before, SBAs are not on the GLP payroll. The company has set up an incentive and per product sales comission structure (see Table 4) to keep SBAs motivated.

Incentives, or sales "boosters" for SBAs are established on the basis of the number of products an SBA sells every month. Figure 5 shows the required number of products sold (in blue) along with the corresponding boosters received listed on the right. Boosters are essentially Sun King products given to SBAs to keep for themselves or to sell at full retail value giving them $100 \%$ of the proceeds from the sale. In addition, SBAs may receive things like irons, sewing machines, and other household appliances equaling the value of certain Sun King products as boosters.

To motivate Team Leaders, GLP has devised a four-tiered promotion and incentive structure for them. This includes a mix of salary increases, target driven monthly sales incentives and benefits (see Table 5). Occasionally TLs have also been rewarded by international travel to solar conferences.

\section{2) Sales Strategy}

A variety of levers are used to drive the sales of Sun King products in the ecosystem in which GLP operates. These levers include marketing tools such as brand building and product demonstrations, and targeted sales and customer relationship building. The Regional Sales Managers (RSMs) are encouraged to 
- One Eco

15

- Two Ecos

- Two Solos

- One Solo + One Pro

- One Mobile + One Pro 2

- Two Sun King Pro 2

Figure 5. Boosters received from achieving target sales.

Table 3. Sample sales of SBAs in Vaishali District, Bihar.

\begin{tabular}{ccc}
\hline SBA & Avg. Monthly Products Sold & Highest Monthly Sale \\
\hline SBA 1 & 21 & 40 \\
SBA 2 & 25 & 65 \\
\hline
\end{tabular}

Table 4. Commission structure for SBAs.

\begin{tabular}{cccc}
\hline Product & Maximum Retail Price (Rs.) & SBA Comission & Billed to SBA \\
\hline Solo & 900 & 80 & 820 \\
Eco & 600 & 60 & 540 \\
Mobile & 1600 & 125 & 1475 \\
Pro 2 & 2300 & 175 & 2125 \\
\hline
\end{tabular}

Table 5. Team leader stucture of promotions and incentives.

\begin{tabular}{ccc}
\hline Level & Monthly Salary (Rs.) & Boost \\
\hline Team Leader 1 & 10,000 & Sales Incentive of Rs. $5-7000 /$ month \\
Team Leader 2 & 10,000 & $\begin{array}{c}\text { Sales Incentive + Rs. } 250 / \text { month } \\
\text { (to cover mobile costs, etc.) }\end{array}$ \\
Team Leader 3 & 10,000 & Monthly Sales incentive + Rs. $500 /$ month \\
& (to cover mobile costs, etc.) \\
Team Leader 4 & 17,000 & $\begin{array}{c}\text { Monthly Sales incentive + Rs. } 500 / \text { month } \\
\text { (to cover mobile costs, etc.) }\end{array}$ \\
\hline
\end{tabular}

come up with innovative localized marketing techniques. The RSM of Vaishali district has taken it upon himself to come up with unique marketing strategies including a ring-tone for his staff's phones that is essentially a sales jingle for Sun King products.

\section{Brand Building}

All Sun King SBAs and TLs wear a bright yellow t-shirt and a cap with the logo so that villagers can recognize the Sun King brand. Leaflets for all products are carried with the GLP staff and taken for door-to-door sales pitches. The leaf-

${ }^{3} 1$ US Dollar = approximately 60 Indian Rupees at the time the survey was conducted. 
let includes the contact information for the local SBA or TL for the customer to contact when they are ready to buy a product (see picture below). Posters of Sun King products are also placed at high-traffic areas such as chai stalls, general stores in villages or at the village chief's house.

In Vaishali district of Bihar, the RSM has employed another unique strategy to build the brand and enhance sales locally. Termed a "van activity", it involves a large Sun King banner draped around a van with a repeated audio announcement about the benefits of solar lighting. This van moves through $5-7$ villages and generates one product sold daily over the course of the two-week activity. An SBA follows up with those customers who may have expressed interest during the time the van was moving through their locality. This activity, another that falls within Rogers' theory [19] of communication networks facilitating the diffusion of innovations, is most effective when conducted prior to the arrival of a sales team to an area.

Another brand building strategy employed by the local RSM is called "Halla Bol". Every Saturday, eight GLP Team Leaders from a region travel through the region on motorcycles wearing Sun King branded shirts, blaring their horns and chanting slogans. This activity is not only a marketing ploy, it also allows TLs from different areas to interact with each other and share information on how to best facilitate sales.

\section{Product Demonstrations}

In the daily product demonstrations an SBA, a TL, and the DSM move together through a village after sunset with switched on Sun King lights hanging around their necks. This draws the attention of the villagers and starts the conversations about the products. Each demonstration activity generates immediate sales and totals approximately $25 \%$ of GLP's sales in Bihar. Most people take leaflets and the SBA follows up with those who showed interest in the product but refrained from purchasing at the time of the demo in the next few days.

GLP staff also target shop owners with Sun King products because they are frequented by many villagers. An SBA might leave a Sun King product at the shop over night with their contact information. A potential customer may then inquire about the lit solar lantern and follow up with the SBA. By leaving a product free of charge with the shop owner for a few days, GLP manages to create awareness and trust in the product. If the shop owner is satisfied with the product they may choose to purchase it instead of risking having it being taken away by GLP staff.

\section{Targeted Sales}

Targeting locations without access to reliable electricity access or approaching businesses that have large lighting needs helps ensure sales. For example, a small poultry farm may require 40 - 45 Sun King lights whereas a brick factory could replace its liquefied petroleum powered lanterns with Sun King products and recuperate the investment in 3 months. In areas identified as having extremely unreliable or no electricity access presents an opportunity to conduct sales by using a general store in the area as a marketing and sales point. 


\section{Competition}

Nationally, GLP competes with many kinds of alternatives to its products. In Bihar, the main competitors for GLP in the market identified by GLP staff are D. Light Design, Bhaskar Solar, G-light, and Sun Max (see Table 6). Products from Sun Max are no longer being sold in the Vaishali district of Bihar. The product offered by G-light resembles the Sun King Eco offered by GLP. Regional Sales Manager for GLP Mr. Bijay Tiwari states that while G-Light retailers tell the customers their products can be used to charge cell phones, the cell phone batteries are not capable of handling such a charge. Ultimately customers find their cell phone performance compromised. As for Bhaskar Solar, their primary product in the region is a solar home lighting system, which is a much bigger and more expensive product for which villagers must approach their Gram Panchayat (village governing body) for financing.

The main competitor most like GLP in the region and nationally is D.Light Design. Though not the focus of this paper, it should be noted that D.Light operates on a completely different business model than GLP, choosing primarily to focus on retailing through partners. In Bihar, D.Light sells its products through the government's "common service centers" (CSC) known as Vasudha Kendra. CSCs serve as a hub for a variety of "high quality and cost-effective video, voice and data content and services, in the areas of e-governance, education, health, telemedicine, entertainment as well as other private services" ${ }^{4 \prime}$.

The graph below shows self-reported annual sales of both GLP and D.Light nationally. Both companies dominate the private solar lantern market in terms of total volumes sold and brand recognized.

\section{3) Customer Relations}

It is important to note the role of building good relationships with customers in order to establish trust in the brand and enhance sales. Trust, Rogers points out, is critical in the adoption of innovations in a target community and something that takes time and key individuals to establish. The GLP model relies on SBAs who are embedded in their local communities and therefore must meet product-servicing requirements as and when they arise. SBAs keep going back to check on customers, which gives them confidence and boosts sales through word

Table 6. GLP competitors in the region.

\begin{tabular}{cccc}
\hline Brand & Product & Price $(\$)$ & Sales Channel \\
\hline D.Light & Kiran lantern & $\$ 8.50-30$ & $\begin{array}{c}\text { Retail through Vasudha Kendra } \\
\text { (government common } \\
\text { service center) }\end{array}$ \\
Bhaskar Solar & Solar Home Lighting System & $>\$ 150$ & $\begin{array}{c}\text { Procured through } \\
\text { Gram Panchayat Fund }\end{array}$ \\
G-Light & Eco-like Lantern & $\$ 15$ & $\begin{array}{c}\text { Retail } \\
\text { Sun Max }\end{array}$ \\
Lanterns & $\$ 30-40$ & $\begin{array}{c}\text { Retail through Kirana Shops } \\
\text { (Convenience Store) }\end{array}$ \\
\hline
\end{tabular}

${ }^{4}$ Source: https://www.csc.gov.in/ 
of mouth amongst the villagers. Villagers are often subjected to "fly-by-night" sales agents who offer faulty products of all kinds so convincing them to purchase a product can be a lengthy and challenging process. Continually asking them about their Sun King products and being visible in the community builds trust.

A closer examination of how these products are diffusing reveals that by targeting the elected head of the village, or another person in the community with high social capital, as the first customer, a lot more products can be sold in the community thereafter. This suggests that GLP products are diffusing locally along the lines of the network theories discussed above. One village chief interviewed said that in the beginning he would have the lantern turned on and placed outside his house during the evenings. People stopping by would inquire about the product. Around 30\% of the respondents stated that they have taken their own or gifted new Sun King products to friends and relatives in other villages. Figure 6 further reveals the power of social capital in diffusing these products: each bubble represents a customer and each number associated with a bubble represents the number of other people that customer managed to convince to purchase a GLP product using their social capital. It was reported that caste may also be a factor in the diffusion of products locally. Caste loyalties are strong in the region and perhaps some groups are facilitating the uptake of Sun King products in their communities better than others.

\section{Maintenance and Servicing}

An important part of maintaining good customer relations is providing quality maintenance and after-sales servicing. Quality maintenance and after-sales service support is one of the most important factors affecting the success of an off-grid solar energy enterprise. Every GLP staff member encountered during the field visit in 2014 seemed to agree that servicing in the area needed improvement. Before the arrival of the Service Center in the nearby city of Patna,

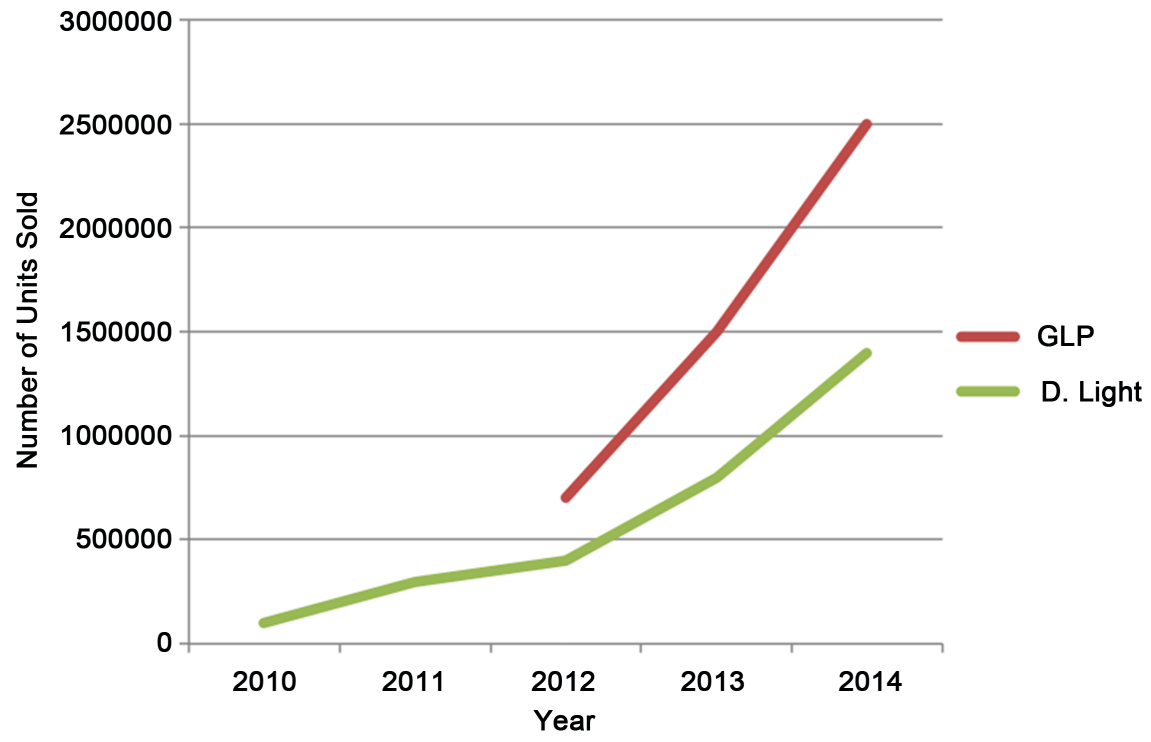

Figure 6. Annual unit sales of GLP and D. Light in India. 
GLP used to simply replace any products facing maintenance issues with brand new ones. The main maintenance problems witnessed by customers in the area are to do with batteries entering a state of "deep discharge" from overuse and mobile charge port malfunction (perhaps due to loose wiring and the quality of the pin used to charge mobile phones).

Once the customer hands over the product to GLP staff, the entire process of repairing and returning should only take 20 days. However, the field visit revealed that one of the biggest challenges faced by GLP's direct marketing business model was delay in the maintenance and repair of products. This delay comes from a few specific parts of the process. Delays in the transportation of broken products to and from a stock point may be one of the biggest problems. The distributor is responsible for this as he is responsible for choosing the transportation courier. In addition, the distributor may wait for a certain number of broken products to collect at the stock point before sending them all together as part of the same consignment to the service center. The sales team may also be responsible for delays by failing to pick up the products from the customers in a timely manner to pass over to the distributor. Figure 7 depicts the process of repairing Sun King products from customer to service center. Elements written in red font in the figure represent areas where delay may be introduced into the process.

\section{Conclusion}

The business innovation of GLP that relies on shifting the risk of conducting sales from the parent corporation to a network of reliable sales agents has given the company an edge in the distribution of off-grid solar technologies in India. By relying on the social capital of the locally embedded sales agents, the company is able to capitalize on the trust required for the adoption of its technology for the last mile customer. In doing so, GLP surmounts one of the biggest barriers cited by theorists as affecting the diffusion of new innovations [19]. The constant

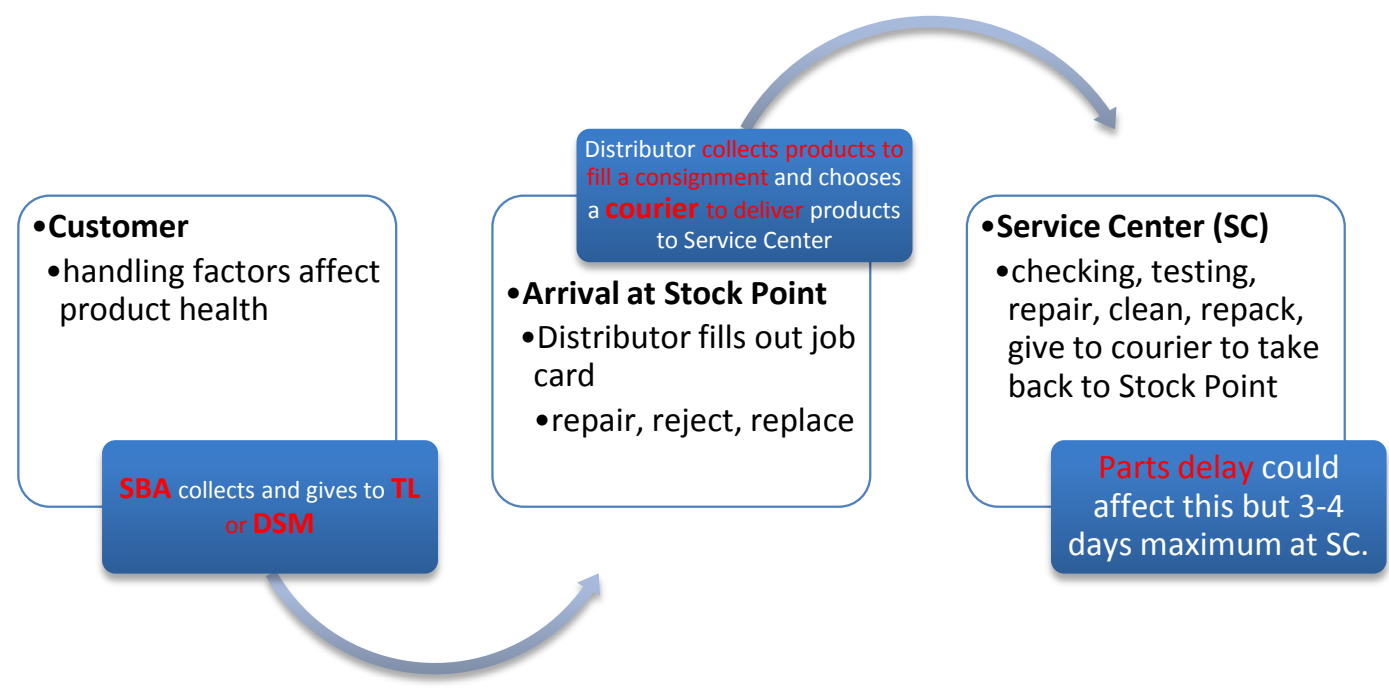

Figure 7. Delays in GLP product servicing chain process. 
communication between the dendritic network representing the company's organizational leadership facilitates the flow of learning on how to conduct and continually improve sales. This structure of communication, so important for understanding customer needs, addresses yet another important factor in facilitating the diffusion of innovations [15] [16]. For taking on the risk of making sales leveraging their social capital within communities, and doing so with strict targets and timelines, sales business associates and team leaders are rewarded by the company through a system of incentives. In conclusion, GLP leverages the most of social and communication networks defined by scholars in order to meet the twin goals of low-carbon technology diffusion as well as expanding (limited) access to modern energy.

\section{Acknowledgements}

I would like to thank my advisors Dr. Kelly Sims Gallagher, Dr. Jenny Aker and Dr. Ambuj Sagar for their guidance and the generous funding from the Center for International Environment \& Resource Policy at the Fletcher School of Law \& Diplomacy, Tufts University. In addition I would like to acknowledge the National Security Education Program (NSEP), which funded my travel to India and for my hosts, the Shakti Sustainable Energy Foundation in New Delhi. Lastly, I would like to thank the institutional homes I had during the time I worked to complete my dissertation and subsequently the post-doctoral work. These institutions include the U.S. Department of Energy, the Center for Global Development (CGD), and the Center for Strategic \& International Studies (CSIS) in Washington, D.C.

\section{References}

[1] UN (2015) Transforming Our World: The 2030 Agenda for Sustainable Development. New York, United Nations, 1-29.

[2] Sovacool, B. (2012) The Political Economy of Energy Poverty: A Review of Key Challenges. Energy for Sustainable Development, 16, 272-282.

[3] Meinshausen, M., Meinshausen, N., Hare, W., Sarah, C.B.R., Frieler, K., Knutti, R., Frame, D.J. and Allen, M.R. (2009) Greenhouse-Gas Emission Targets for Limiting Global Warming to $2^{\circ} \mathrm{C}$. Nature, 458, 1158-1162.

[4] Wilson, C. (2009) Meta-Analysis of Unit and Industry Level Scaling Dynamics in Energy Technologies and Climate Change Mitigation Scenarios. Interim Report, Laxenburg, Austria, IIASA, 1-119.

[5] Casillas, C.E., and Kammen, D.M. (2011) The Delivery of Low-Cost, Low-Carbon Rural Energy Services. Energy Policy, 39, 4520-4528.

[6] Singh, K. (2016) Business Innovation and Diffusion of Off-Grid Solar Technologies in India. Energy for Sustainable Development, 30, 1-13.

[7] Byrne, R., Smith, A., Watson, J. and Ockwell, D. (2011) Energy Pathways in Low-Carbon Development: From Technology Transfer to Socio-Technical Transformation. STEPS Working Paper 46, Brighton, STEPS Centre, 1-81.

[8] Balachandra, P. (2011) Modern Energy Access to All in Rural India: An Integrated Implementation Strategy. Energy Policy, 39, 7803-7814. 
[9] Palit, D. and Chaurey, A. (2011) Off-Grid Rural Electrification Experiences from South Asia: Status and Best Practice. Energy for Sustainable Development, 15, 266 276.

[10] Chaurey, A., et al. (2012) New Partnerships and Business Models for Facilitating Energy Access. Energy Policy, 47, 48-55.

[11] Palit, D., Sovacool, B., Cooper, C., Zoppo, D., Eidsness, J., Crafton, M., Johnson, K. and Clarke, S. (2013) The Trials and Tribulations of the Village Energy Security Programme (VESP). Energy Policy, 57, 407-417.

[12] Schumpeter, J. (1934) The Theory of Economic Development. Harvard University Press, Cambridge.

[13] Agbemabiese, L., Nkomo, J. and Sokona, Y. (2012) Enabling Innovations in Energy Access: An African Perspective. Energy Policy, 47, 38-47.

[14] Barnett, A. (1990) The Diffusion of Energy Technology in the Rural Areas of Developing Countries: A Synthesis of Recent Experience. World Development, 18, 539-553.

[15] Sechrest, L., Stewart, M. and Stickle, T. (1998) Factors Affecting the Adoption and Impact of CGIAR Innovations: A Synthesis of Findings. CGIAR, Washington DC, $1-56$.

[16] Ockwell, D. and Mallett, A. (2012) Introduction. Low-Carbon Technology Transfer: From Rhetoric to Reality. Routledge, Abingdon, 3-19.

[17] Gallagher, K.S., Grubler, A., Kuhl, L., Nemet, G.F. and Wilson, C. (2012) The Energy Technology Innovation System. Annual Review of Environment and Resources, 37, 137-162. https://doi.org/10.1146/annurev-environ-060311-133915

[18] Suurs, R.A.A. (2009) Motors of Sustainable Innovation: Towards a Theory on the Dynamics of Technological Innovation Systems. Utrecht University, Utrecht.

[19] Rogers, E. (2003) Diffusion of Innovations. The Free Press, New York.

[20] Aker, J.C. (2007) Social Networks and Household Welfare in Tanzania: Working Together to Get out of Poverty. Social Science Research Network, 1-33.

[21] Valente, T.W. (1996) Social Network Thresholds in the Diffusion of Innovations. Social Networks, 18, 69-89.

[22] Caird, S., Roy, R. and Herring, H. (2008) Improving the Energy Performance of UK Households: Results from Surveys of Consumer Adoption and Use of Low-and Zero-Carbon Technologies. Energy Efficiency, 1, 149-166.

[23] McEachern, M. and Hanson, S. (2008) Socio-Geographic Perception in the Diffusion of Innovation: Solar Energy Technology in Sri Lanka. Energy Policy, 36, 25782590.

[24] Ramirez, S., Dwivedi, P., Ghilardi, A. and Bailis, R. (2014) Diffusion of Non-Traditional Cook Stoves across Western Honduras: A Social Network Analysis. Energy Policy, 66, 379-389.

[25] Tawney, L., Miller, M. and Bazilian, M. (2013) Innovation for Sustainable Energy from a Pro-Poor Perspective. Climate Policy, 15, 146-162. https://doi.org/10.1080/14693062.2013.781456

[26] Gallagher, K.S., Holdren, J. and Sagar, A. (2006) Energy Technology Innovation. Annual Review of Environment and Resources, 31, 193-237. https://doi.org/10.1146/annurev.energy.30.050504.144321

[27] Wasserman, S. and Faust, K. (1994) Social Network Analysis: Methods and Applications. Cambridge University Press, New York. https://doi.org/10.1017/cbo9780511815478 
[28] Bairiganjan, S. and Sanyal, S. (2013) The Last 50 Mile: Using LVE Networks for Increasing Clean Energy Access. New Ventures India, Hyderabad, 1-49.

[29] Mentzer, J., DeWitt, W., Keebler, J., Min, S., Nix, N.W., Smith, C.D. and Zacharia, Z. (2001) Defining Supply Chain Management. Journal of Supply Chain Management, 22, 1-25. https://doi.org/10.1002/j.2158-1592.2001.tb00001.x

Submit or recommend next manuscript to SCIRP and we will provide best service for you:

Accepting pre-submission inquiries through Email, Facebook, LinkedIn, Twitter, etc. A wide selection of journals (inclusive of 9 subjects, more than 200 journals)

Providing 24-hour high-quality service

User-friendly online submission system

Fair and swift peer-review system

Efficient typesetting and proofreading procedure

Display of the result of downloads and visits, as well as the number of cited articles

Maximum dissemination of your research work

Submit your manuscript at: http://papersubmission.scirp.org/

Or contact lce@scirp.org 